\title{
TINTERthesis
}

\section{O MOMENTO NOS EXIGE MUDAR...}

The moment calls for us to change...

Luiz Fernando Greiner Barp Doutorando em Ciências Humanas pela Universidade Federal de Santa Catarina. Editor Assistente da revista INTERthesis. Universidade Federal de Santa Catarina, Florianópolis, Brasil barp.If@gmail.com https://orcid.org/0000-0001-5256-8712

Javier Ignacio Vernal Doutor em Filosofia pela Universidade Federal de Santa Catarina Editor da revista INTERthesis. Universidade Federal de Santa Catarina, Florianópolis, Brasil jivernal@gmail.com

\section{https://orcid.org/0000-0003-4014-6656}

A revista INTERthesis nasce, em 2004, amparada na convicção da interdisciplinaridade como instrumento para tentar compreender, de forma abrangente, os fenômenos sociais. Como alternativa às abordagens disciplinares, utilizamos do conceito "interdisciplinar" para guiar um periódico interessado no avanço do conhecimento científico por meio de suas diferentes manifestações, especialmente relacionadas com a área das Ciências Humanas. Compartilhando da visão de Claude Raynaut (RAYNAUT, 2014), assumimos desde o nosso primeiro volume o desafio de compreender os resultados científicos muito mais como uma prática em andamento, que como um exercício orientado por epistemologias e metodologia perfeitamente definidas.

Ocorre que aliado a esse pensamento constante, os anos mais recentes também nos fizeram repensar a forma com que utilizamos de nosso espaço para divulgar os trabalhos científicos. E neste momento de interrogações, uma revista com novas características passa a ser publicada; que gostaríamos de apresentar aos que nos leem. Contudo, antes de mais nada, é preciso situar o tempo e o espaço em que nos encontramos, pois ele justifica as decisões tomadas.

A virada político-social ultraconservadora que o Brasil vem experimentando recentemente pode ser encarada como um novo ponto de partida, pois afeta diversas frentes, entre as quais nos situamos por meio da ciência e da educação. Exemplo disso tivemos ao longo de 2019, quando o atual governo congelou repasses financeiros às 
universidades federais e suspendeu bolsas de estudo em nível de mestrado e doutorado, prejudicando projetos de pesquisa e extensão em andamento. Ainda, fez promessas de mudanças nos critérios de concessão de novas bolsas de pesquisa, deixando claro seu projeto que priorizaria campos disciplinares estratégicos, nos quais estariam excluídos as humanidades.

Além disso, a possibilidade da fusão da Coordenação de Aperfeiçoamento de Pessoal de Nível Superior (Capes) com o Conselho Nacional de Desenvolvimento Científico e Tecnológico (CNPQ), esboçada durante o último ano, alerta para as mudanças catastróficas que podem ser esperadas ainda neste governo, que começa 2020 com a nomeação de um defensor do criacionismo como novo presidente da Capes. Mudanças que prejudicam o desenvolvimento educacional e científico no país, seja por meio da redução de recursos, do sucateamento de laboratórios de pesquisa, além de eventuais direcionamentos que priorizam áreas do conhecido enquanto excluem outras, fortemente atacadas por seus posicionamentos críticos frente a certas decisões políticas arbitrárias.

Episódios como os acima citados não somente devem ser vistos em tom de preocupação, como materializam o jogo de forças que incide sobre o campo científico; espaço que sofre com imposições e solicitações, eximindo a possibilidade da realização de uma "ciência pura" (BOURDIEU, 2003). Ao mesmo tempo, mobilizam-nos para que reivindiquemos a defesa da manutenção e da autonomia dos campos científicos, o que por si só torna-se um ato político,

[...] especialmente num momento e em sociedades nas quais os homens políticos e os dirigentes econômicos se armam, sem cessar, da ciência, economia principalmente, não para governar, como o querem fazer crer, mas para legitimar uma ação política inspirada por razões que nada têm de científicas (BOURDIEU, 2003, p. 68).

A fim de que possamos enriquecer nosso capital científico, com intuito de resistir às (o)pressões que se impõem à ciência neste momento, implantamos mudanças em nossa forma de publicação. A primeira delas diz respeito às Diretrizes para Autores da revista que foram atualizadas. Entre as principais modificações está a adoção de templates, que detalham os estilos das seções e a adoção do arquivo Notas de Autor/a1 ${ }^{1}$. Essas

\footnotetext{
${ }^{1}$ Ver https://periodicos.ufsc.br/index.php/interthesis/about/submissions\#authorGuidelines
} 
mudanças, mais do que meramente formais, estéticas ou editoriais, fomentam um trabalho sério, devidamente creditado e com uma identidade própria da INTERthesis.

Outra novidade diz respeito à inserção de eixos temáticos específicos em nossas publicações. Embora sempre abertos a repercutir reflexões sobre problemáticas sociais diversas, por meio de nossas quatro áreas de concentração (África e suas Diásporas; Condição Humana na Modernidade; Estudos de Gênero; e Sociedade e Meio Ambiente), decidimos, a partir deste ano, dedicar um espaço para pesquisas que oportunizem a reflexão crítica a respeito de temáticas constantemente ameaçadas em tempos presentes. Nesse contexto, ao longo de 2020 teremos, além dos trabalhos habituais recebidos em fluxo contínuo, a publicação de artigos pertencentes aos dois eixos temáticos, cujas chamadas foram lançadas anteriormente: "Amazônia: povos, conflitos e preservação" e “(Re)discutindo sexualidade: corpo, prazer e desejo em tempos conservadores".

O primeiro eixo nasce frente às ameaças que a região amazônica sofre, e que ganharam destaque nacional e internacional no segundo semestre do ano anterior, tais como os inúmeros episódios de queimadas e, consequentemente, a devastação de sua fauna e flora, e no presente, com o projeto de lei que busca aprofundar a exploração de terras indígenas. Diante disso, ao longo deste ano publicaremos pesquisas empíricas e reflexões teóricas de fenômenos socioecológicos relativos a essa região em uma perspectiva interdisciplinar. Dessa forma esperamos contribuir minimamente com a manutenção dessa região que os setores políticos e econômicos parecem negligenciar.

Em paralelo, a INTERthesis também direciona seus olhares à diversidade sexual; questão que por um lado vem assumido lugares de visibilidade e reivindicação de direitos, e por outro segue sendo duramente atacada e/ou ignorada, a exemplo da recente campanha lançada pelo governo federal que, para conter novos casos de gravidez na adolescência, ignora a educação sexual e prefere defender a abstinência; alternativa essa que recusa qualquer embasamento científico em prol de convicções ideológicas. Tal situação demonstra como corpo, prazer e desejo se tornaram objetos de disputas políticas e sociais, como celebremente já antecipou Foucault (2017). Portanto, refletir cientificamente sobre questões acerca da sexualidade se torna uma tarefa essencial, como forma de contribuir para que vozes historicamente silenciadas preservem e/ou reivindiquem seus direitos de existência e de expressão.

Por fim, a INTERThesis passa a adotar neste ano sua publicação de forma contínua. Essa mudança não apenas modifica nossos processos internos de recebimento e avaliação dos trabalhos recebidos, como busca agilizar o processo de publicação, 
dispensando a necessidade do lançamento de um novo número da revista para que nosso corpo de artigos seja atualizado e disponibilizado para o acesso e leitura. Com isso, unimo-nos a outros periódicos de referência nacional e internacional que vêm assumido a vanguarda na forma de publicar resultados científicos visando sua celeridade e qualidade.

Agradecemos ao nosso corpo de autores/as, leitores/as e avaliadores/as por seguirem acreditando e colaborando com o trabalho desenvolvido pela INTERthesis ao longo desses anos. Com essas mudanças, esperamos em 2020 continuar contribuindo com o avanço do conhecimento científico em suas diferentes perspectivas interdisciplinares e, mais do que isso, somarmos força ao movimento que resiste aos ataques que a educação e a ciência, especialmente as Ciências Humanas, vêm recebendo nos últimos anos.

\section{REFERÊNCIAS}

BOURDIEU, Pierre. Os usos sociais da ciência: por uma sociologia clínica do campo científico. São Paulo, Fundação Editora da UNESP, 2003.

FOUCAULT, Michel. História da sexualidade 1: A vontade de saber. $4^{\mathrm{a}}$ ed. Rio de Janeiro/São Paulo: Paz \& Terra, 2017.

RAYNAUT, Claude. Os desafios contemporâneos da produção do conhecimento: o apelo para interdisciplinaridade. Interthesis, vol 11, n. 01, jan/jun 2014, pp. 1-22. Acessível em: https://periodicos.ufsc.br/index.php/interthesis/article/view/1807-

$1384.2014 \mathrm{v} 11 \mathrm{n} 1 \mathrm{p} 1 / 26883$ 